\title{
MORPHOLOGICAL VARIATION OF JUNIPERUS OXYCEDRUS SUBSP. MACROCARPA (CUPRESSACEAE) IN THREE ITALIAN LOCALITIES
}

\author{
MAŁGORZATA KLIMKO ${ }^{1}$, KRYSTYNA BORATYŃSKA ${ }^{2}$, \\ ADAM BORATYŃSKI ${ }^{2}$, KATARZYNA MARCYSIAK ${ }^{3}$ \\ ${ }^{1}$ August Cieszkowski Agricultural University, Department of Botany \\ Wojska Polskiego 71 C, 60-625 Poznań, Poland \\ e-mail:klim@owl.au.poznan.pl \\ 2 Polish Academy of Sciences, Institute of Dendrology \\ Parkowa 5, 62-035 Kórnik, Poland \\ ${ }^{3}$ Pedagogic University, Institute of Biology and Environment Conservation \\ Laboratory of Botany \\ Chodkiewicza 30, 80-064 Bydgoszcz, Poland
}

(Received: July 11, 2003. Accepted: March 2, 2004)

\begin{abstract}
The intra- and interpopulational geographic variation of three distant populations of J. oxycedrus subsp. macrocarpa was examined biometrically on the basis of morphological key-characters of needles, seeds and cones. The shortest Euclidean distances were used in the agglomerative grouping of closest neighbourhood and discrimination analysis with principal component analysis (PCA) was performed to verify the south-north differentiation of the taxon in Italy. Most of the cone and seed dimensional characters are correlated. No significant correlations were found between cone and needle characters. The sampled populations differ only insignificantly from one another, while the intrapopulational variation is slightly higher. Cone length as well as seed number, width and thickness were significantly correlated with geographic latitude, while the other four characters are not. Differences in cone shape were observed between individuals, so that several morphotypes can be distinguished.
\end{abstract}

KEY WORDS: Juniperus oxycedrus, taxonomy, variation, biometry.

\section{INTRODUCTION}

Juniperus oxycedrus L. belongs to the section Oxycedrus of the genus Juniperus. It is a variable species with three subspecies (Greuter et al. 1984) that differ in habit, cone size and needle width (Amaral Franco 1963, 1964, 1968, 1986; Lebreton et al. 1991). One of them is subsp. macrocarpa (Sibth. \& Sm.) Ball [in J. Lin. Soc., Bot. 16: 670 (1878)], sometimes treated as an independent species $J$. macrocarpa Sibth. \& Sm. [Fl. Graec. Prodr. 2: 263 (1816)] (Boratyński et al. 1992; Browicz 1996; Adams 2000).

Juniperus oxycedrus subsp. macrocarpa is a tree, in good conditions reaching $10-12 \mathrm{~m}$ in height. It has large cones, 1.2-1.5 mm across, light to dark brown or somewhat purplish and pruinose. Its needles are up to $2.5 \mathrm{~mm}$ wide (Amaral Franco 1986; Browicz 1996). It occurs on dunes or maritime rocks along the Mediterranean coast (Fig. 1) and sometimes forms groves, as for example in Italy, Spain, Greece, Tunisia and Morocco (Quezel and Pesson
1980; Boratyński 1992). The coastal distribution of the species makes it extremely vulnerable and endangered. The many seaside resorts constructed during last decades were recognized as reason of species disappearance on most of their localities known from herbaria and literature (Zaafouri and Chaieb 1999; Pastor and Juan 1999; Arista et al. 2001).

Juniperus oxycedrus subsp. macrocarpa has not been an object of detailed biometric investigations so far. The variability of cone dimensions was examined on the basis of single individuals, mainly from France, Spain and North-West Africa (Lebreton et al. 1991). The results stress the differences between subsp. oxycedrus and subsp. macrocarpa and lack of significant differences between these taxa and subsp. badia. This was confirmed in a parallel study of prodelphinidin content in needles (Lebreton et al. 1991). Four populations in Spain, represented by ten individuals each, have been lately compared on the basis of cone diameter and weight and seed number per cone, showing si- 


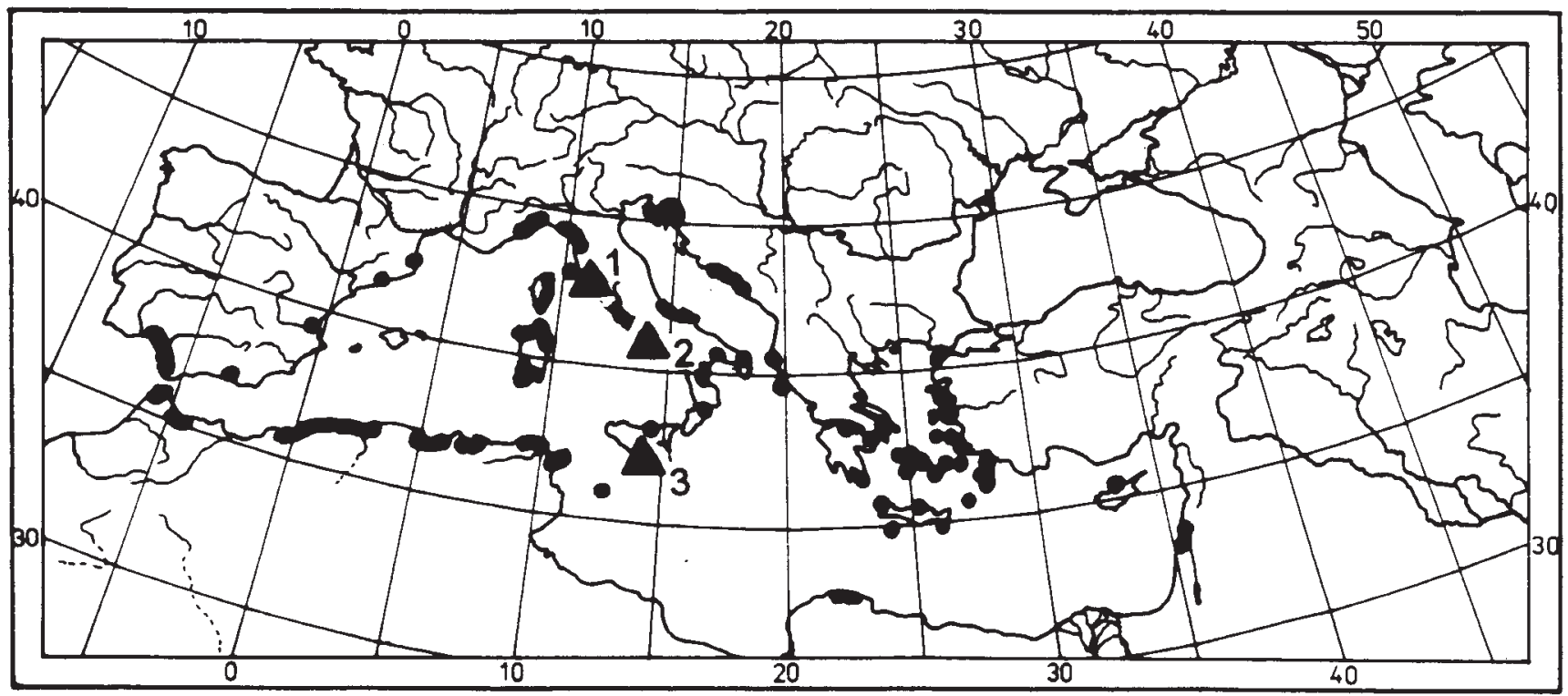

Fig. 1. Range of Juniperus oxycedrus subsp. macrocarpa (after Jalas and Suominen 1973; Browicz 1996; Lewandowski et al. 1996, verified and supplemented); location of sampled populations: 1 - Toscany, Orbetello, forest on maritime dunes E $11^{\circ} 15^{\prime} 00^{\prime \prime}, \mathrm{N}^{\circ} 42^{\circ} 26^{\prime} 45^{\prime \prime} ; 2$ - Sabaudia, forest on maritime

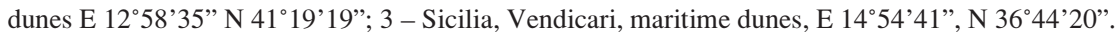

gnificant interpopulational differences (Rocio et al. 2003). The isoenzyme variation in an island population of the taxon from Korfu appears to be low (Lewandowski et al. 1996).

The aim of the present study was to compare biometrically three distant populations of Juniperus oxycedrus subsp. macrocarpa on the basis of the characters of cones, seeds and needles, as previously in the case of $J$. phoenicea (Mazur et al. 2003).

\section{MATERIAL AND METHODS}

Three maritime populations of Juniperus oxycedrus subsp. macrocarpa in Italy were sampled in September 2001 (Fig. 1). In total, 75 individuals were sampled. From each individual, 10-15 ripe cones and 10-15 one-year-old needles were collected from the sunny, mostly southern parts of the crowns (including the south-eastern and southwestern expositions), at the height of 1.0-2.0 m.

The eight morphological characters and three ratios were examined to determine the variation of every individual (Table 1).

The main statistics, i.e. arithmetic mean, standard deviation and variation coefficient, were calculated for every individual separately and for each population, and later the

TABLE 1 . Analysed characters of cones, seeds and needles.

\begin{tabular}{clc}
\hline No. & Character & Accuracy \\
\hline 1 & Cone length & $0.1 \mathrm{~mm}$ \\
2 & Cone diameter & $0.1 \mathrm{~mm}$ \\
3 & Seed number per cone & \\
4 & Seed length & $0.1 \mathrm{~mm}$ \\
5 & Seed width & $0.1 \mathrm{~mm}$ \\
6 & Seed thickness & $0.1 \mathrm{~mm}$ \\
7 & Needle length & $0.1 \mathrm{~mm}$ \\
8 & Needle width & $0.1 \mathrm{~mm}$ \\
9 & Ratio of cone length/width (1/2) \\
10 & Ratio of cone diameter/seed number $(2 / 3)$ & \\
11 & Ratio of seed length/width (4/5) & \\
\hline
\end{tabular}

three local populations were compared. The interactions among characters were tested by using the Pearson's correlation coefficient. The discriminating value of characters was verified with the Tukey's post hoc test and with analysis of dicriminant function of characters (Zar 1999; Łomnicki 2000). The shortest Euclidean distances were calculated in agglomerative grouping by the method of the closest neighbourhood, and dendrograms were constructed to examine the relationships within and between populations (Karoński and Caliński 1973; Sokal and Rohlf 1997). A discriminant analysis was performed and the position of the specimens was tested along the first two discriminant variables to find differences among populations and individuals (Krzyśko 1979; Morrison 1990; Underwood 1997; Sokal and Rohlf 1997). The interaction of values of particular characters with geographic longitude and latitude were verified using Pearson's r correlation coefficient (Zar 1999).

\section{RESULTS}

The frequency distribution of all the examined characters appears to be normal, with only slight left or right bias. This confirms that the numbers of data are sufficient, the samples are homogenous and enable the statistical analysis of the data.

Mean values, ranges, standard deviations and variation coefficients are presented for every population separately and for all individuals combined (Table 2). On average, cones are $15.5 \mathrm{~mm}$ length (character 1) and $14.5 \mathrm{~mm}$ in diameter (character 2), but values of these characters varied between 12.0 and $22.2 \mathrm{~mm}$ and between 11.0 and $19.3 \mathrm{~mm}$, respectively. Within each individual, the dimensions of cones are generally invariable, with variation coefficient not higher than $10 \%$ in every sample analysed. The ratio of cone length/diameter (character 9) and all measured characters of seeds are stable (Table 2). In each population, cone shape varies considerably, and three morphotypes can be distinguished: spherical, ellipsoid, and pear-shaped (Fig. 2). The number of seeds per cone (character 3 ), ranging from 1 
TABLE 2. Statistic description of the analysed 11 characters of Juniperus oxycedrus subsp. macrocarpa (numbers 1-11 names as in Table 1).

\begin{tabular}{|c|c|c|c|c|c|c|c|c|c|c|c|c|}
\hline \multirow{2}{*}{ Statistics } & \multirow{2}{*}{ Sample } & \multicolumn{11}{|c|}{ Character } \\
\hline & & 1 & 2 & 3 & 4 & 5 & 6 & 7 & 8 & 9 & 10 & 11 \\
\hline \multirow[t]{4}{*}{ Mean } & Sabaudia & 16.24 & 14.53 & 2.95 & 8.89 & 4.97 & 4.33 & 12.10 & 2.04 & 1.12 & 5.00 & 1.80 \\
\hline & Orbetello & 14.48 & 14.57 & 2.76 & 8.83 & 5.45 & 4.68 & 11.96 & 2.03 & 1.00 & 5.31 & 1.62 \\
\hline & Vendicari & 15.61 & 14.45 & 2.78 & 8.73 & 5.58 & 4.59 & 10.40 & 1.98 & 1.08 & 5.23 & 1.58 \\
\hline & All samples & 15.52 & 14.52 & 2.85 & 8.84 & 5.27 & 4.50 & 11.65 & 2.02 & 1.07 & 5.16 & 1.69 \\
\hline \multirow[t]{4}{*}{ Minimum } & Sabaudia & 12.2 & 11.0 & 1.0 & 6.0 & 3.4 & 3.2 & 5.0 & 1.0 & 0.85 & 3.40 & 1.24 \\
\hline & Orbetello & 12.2 & 11.8 & 1.0 & 6.0 & 3.6 & 3.2 & 5.0 & 1.0 & 0.80 & 4.16 & 1.08 \\
\hline & Vendicari & 12.0 & 11.8 & 1.0 & 6.4 & 3.6 & 3.3 & 5.5 & 1.0 & 0.82 & 4.47 & 1.0 \\
\hline & All samples & 12.0 & 11.0 & 1.0 & 6.0 & 3.4 & 3.2 & 5.0 & 1.0 & 0.80 & 3.40 & 1.0 \\
\hline \multirow[t]{4}{*}{ Maximum } & Sabaudia & 22.2 & 19.0 & 5.0 & 11.5 & 7.4 & 6.4 & 18.5 & 3.0 & 1.56 & 6.52 & 2.73 \\
\hline & Orbetello & 18.0 & 18.8 & 6.0 & 14.7 & 7.2 & 6.6 & 20.0 & 3.0 & 1.32 & 6.20 & 2.64 \\
\hline & Vendicari & 21.8 & 19.3 & 5.0 & 11.5 & 8.2 & 6.6 & 17.0 & 3.0 & 1.36 & 6.55 & 2.30 \\
\hline & All samples & 22.2 & 19.3 & 6.0 & 14.7 & 8.2 & 6.6 & 20.0 & 3.0 & 1.56 & 6.55 & 2.73 \\
\hline \multirow[t]{4}{*}{ Standard deviation } & Sabaudia & 1.3502 & 1.1773 & 0.3650 & 0.6032 & 0.3626 & 0.3836 & 2.0387 & 0.5720 & 0.1305 & 0.678 & 0.1282 \\
\hline & Orbetello & 1.0880 & 1.3393 & 0.2223 & 1.0018 & 0.4601 & 0.5746 & 2.3774 & 0.3088 & 0.0683 & 0.684 & 0.1254 \\
\hline & Vendicari & 1.5250 & 1.3682 & 0.3365 & 0.7519 & 0.5908 & 0.4199 & 1.8910 & 0.3582 & 0.0977 & 0.577 & 0.1489 \\
\hline & All samples & 1.5085 & 1.2605 & 0.3273 & 0.7767 & 0.5268 & 0.4822 & 2.2081 & 0.4484 & 0.1186 & 0.666 & 0.1639 \\
\hline \multirow[t]{4}{*}{ Variation coefficient } & Sabaudia & 8.32 & 8.10 & 12.37 & 6.78 & 7.30 & 8.87 & 16.84 & 28.03 & 11.61 & 13.62 & 7.14 \\
\hline & Orbetello & 7.52 & 9.19 & 8.05 & 11.35 & 8.44 & 12.28 & 19.88 & 15.24 & 6.85 & 12.88 & 7.74 \\
\hline & Vendicari & 9.77 & 9.47 & 12.09 & 8.61 & 10.59 & 9.15 & 18.18 & 18.07 & 9.02 & 11.02 & 9.45 \\
\hline & All samples & 9.72 & 8.68 & 11.48 & 8.79 & 10.00 & 10.71 & 18.95 & 22.18 & 11.04 & 12.93 & 9.72 \\
\hline
\end{tabular}

to 6 , is moderately variable, with variation coefficient more than $11 \%$ (Table 2). Needle length (character 7 ) is also variable, with variation coefficient from 17 to $20 \%$ in particular samples, and the needle width (character 8 ) is very variable too, with variation coefficient from $15 \%$ to $28 \%$ (Table 2).

Generally, dimensional characters are positively significantly correlated in whole three samples. Only in Sabaudia (sample 1), cone length (character 1) and cone diameter (character 2), as well as needle length and width (characters 7 and 8) do not correlate significantly. The characters of needles do not correlate with characters of cones and seeds, except of sample from Orbetello, where number of seeds per cone (character 3 ) is significantly negatively correlated with needle length (character 8 ). The characters of cones and seeds are significantly positively correlated in all three samples.

The whole material indicates about $30 \%$ statistically significant correlations between characters at the level $\mathrm{p}<0.01$. Significant positive correlations were observed for cone length and diameter (characters 1 and 2, respectively), as well as seed length, width and thickness (characters 4, 5 and 6, respectively). The two needle characters are correlated with each other only, while seed number per cone did not show any significant positive correlations.

The cone length, seed width and thickness, needle length and ratios of cone length/width and seed length/width (characters number $1,5,6,7,9$ and 11 , respectively) discriminate statistically significantly between sampled populations in Tykey's post hoc test (Fig. 3). The analysis of discriminant function showed that only needle length discriminates statistically significantly at $\mathrm{p}=0.028$.
The dendrogram from Orbetello includes 24 individuals. In the dendrogram it can be divided into three subgroups. In the first subgroup the greatest similarity is observed between individuals 10 and 9; 8 and 2 . Within the second between 21 and 4; 17 and 22; 13 and 14. The third subgroup contains one pair of individuals 16 and 20. In dendrogram from Orbetello the most distinct is individual 12. The cones of this individual were pear-shaped (cone length) width ratio $0.90)$, its seeds were very elongated and needles were short (Fig. 4).

Dendrogram of Juniperus oxycedrus subsp. macrocarpa of sample (Sabaudia), includes 33 individuals. We can distinguish one large group, which can be divided into few subgroups. The greatest similarity is observed between individuals 28 and 25; 29 and 10; 14 and 7; 30 and 16; 32 and 13 . In the dendrogram, the most distinct are individuals 19 and 6; 20 and 1. Individuals 19 and 6 characterized by short needles, long and narrow cones. Individuals 1 and 20 have very long needles, and little seeds (Fig. 4).

The dendrogram from Vendicari shows 18 individuals. Most individuals form one large group, and the greatest similarity is observed within three pairs of individuals: 7 and $11 ; 15$ and $12 ; 3$ and 2 . The most distinct is individual 14 characterized by short and narrow cones and seeds, its needles were broadly (Fig. 4). Local populations are characterized by peculiar features, which may be due to the influence of the environment or could develop in each area in a specific way.

The variation range was lower in the most numerous population from Sabaudia, while differences among individuals were larger in population from Orbetello and Vendicari. 

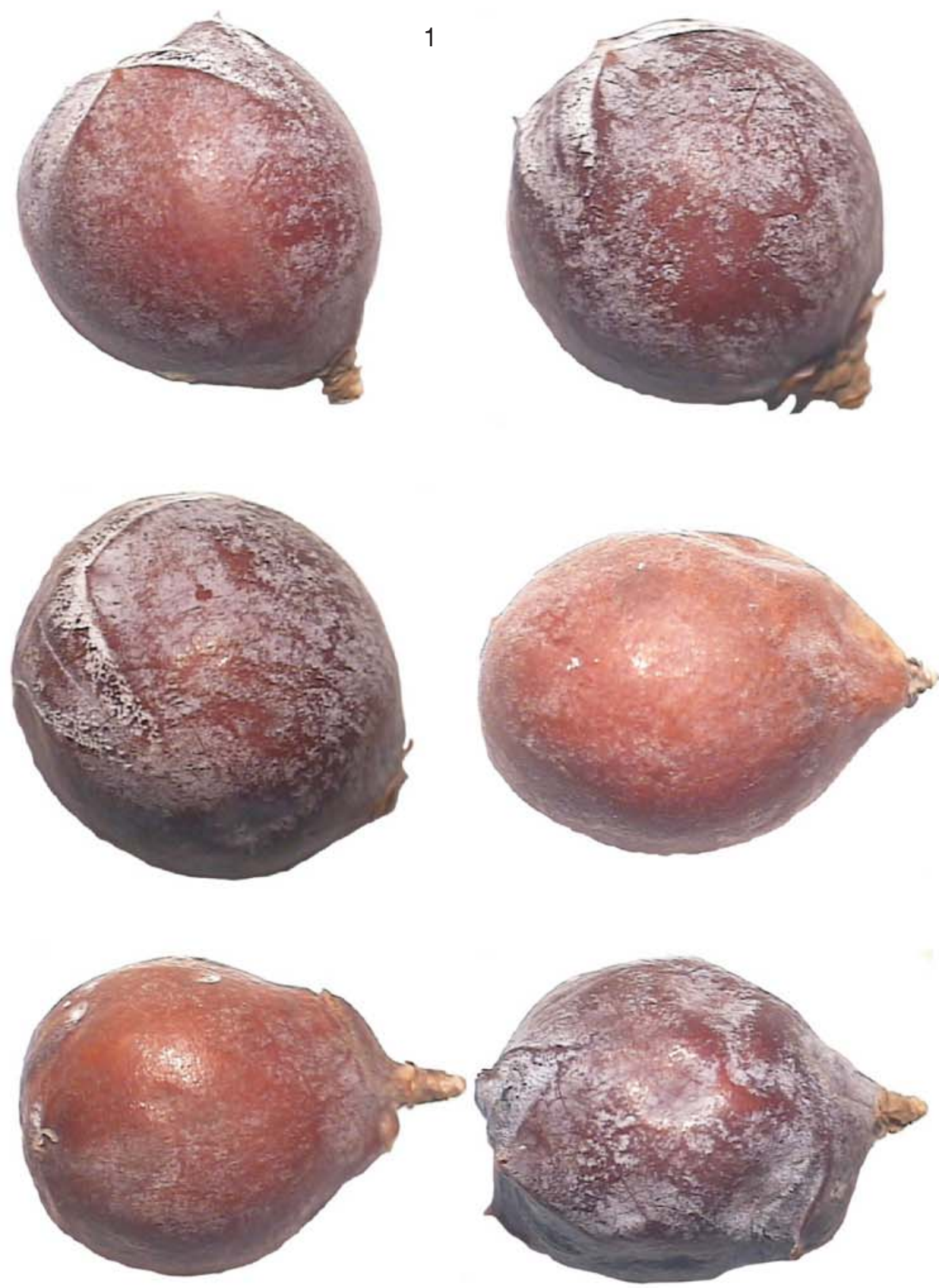

2
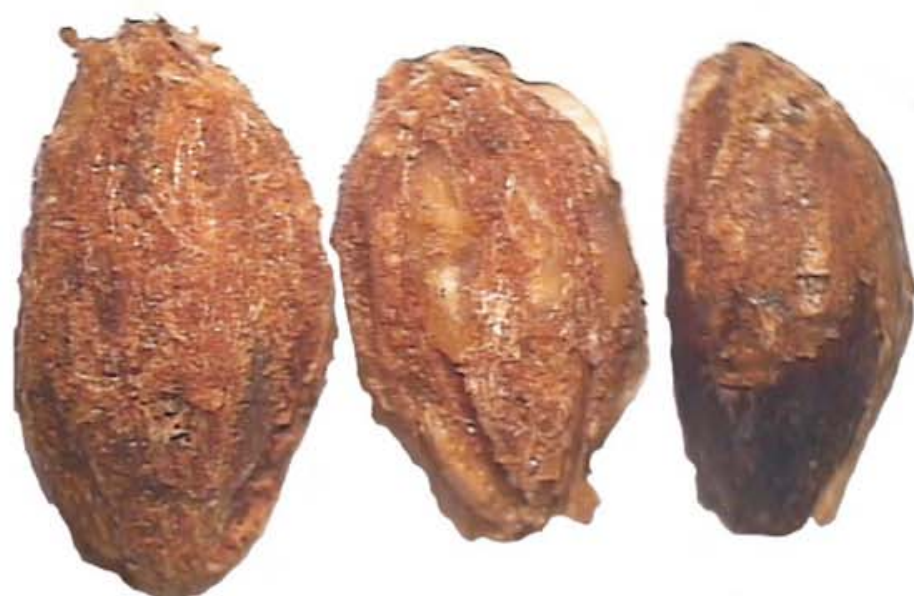

Fig. 2. Morphological types of cones (1) and seeds (2) of Juniperus oxycedrus subsp. macrocarpa. 

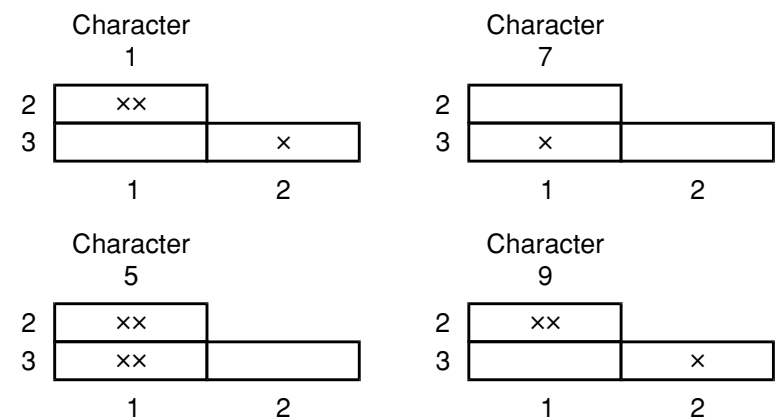

Character
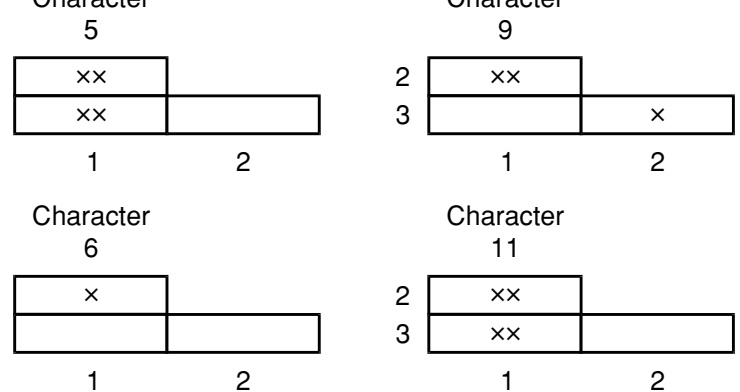

Fig. 3. Characters differentiating populations in Tukey's test; $x \times-$ statistically significant at $\mathrm{p}=0.01, \times-$ statistically significant at level $\mathrm{p}=0.05$; characters not differentiating statistically significantly omitted.

Homogeneity of all populations was tested together with analysis of discriminant variables. The individuals from all three samples form one group on the plane of the first two discriminant variables $\left(\mathrm{U}_{1}\right.$ and $\left.\mathrm{U}_{2}\right)$, which are responsible of $100 \%$ of total variation. The discriminant variable $\mathrm{U}_{1}$ is determined mostly by ratio seed length/width (character 11), seed width (character 5), cone length (character 1) and ratio of cone length/width (character 9), while $\mathrm{U}_{2}$ by needle length (character 7) and cone length (character 1). All individuals form one group composed of three overlapping agglomerations of the three analysed samples (Fig. 5). The most distinct is the sample from Sabaudia. The differences are determined mostly by variable $\mathrm{U}_{1}$, which covers about $70 \%$ of total variability measured. The samples from Orbetello and Vendicari are closer to each other in respect of variable $\mathrm{U}_{1}$ and slightly differentiated in respect of variable $\mathrm{U}_{2}$ (Fig. 5). Similar relations among samples are confirmed by the dendrogram constructed on the basis of the shortest Euclidean distances (Fig. 6).

Seed width and thickness are positively, while cone length and seed number are negatively significantly correlated with geographic latitude.
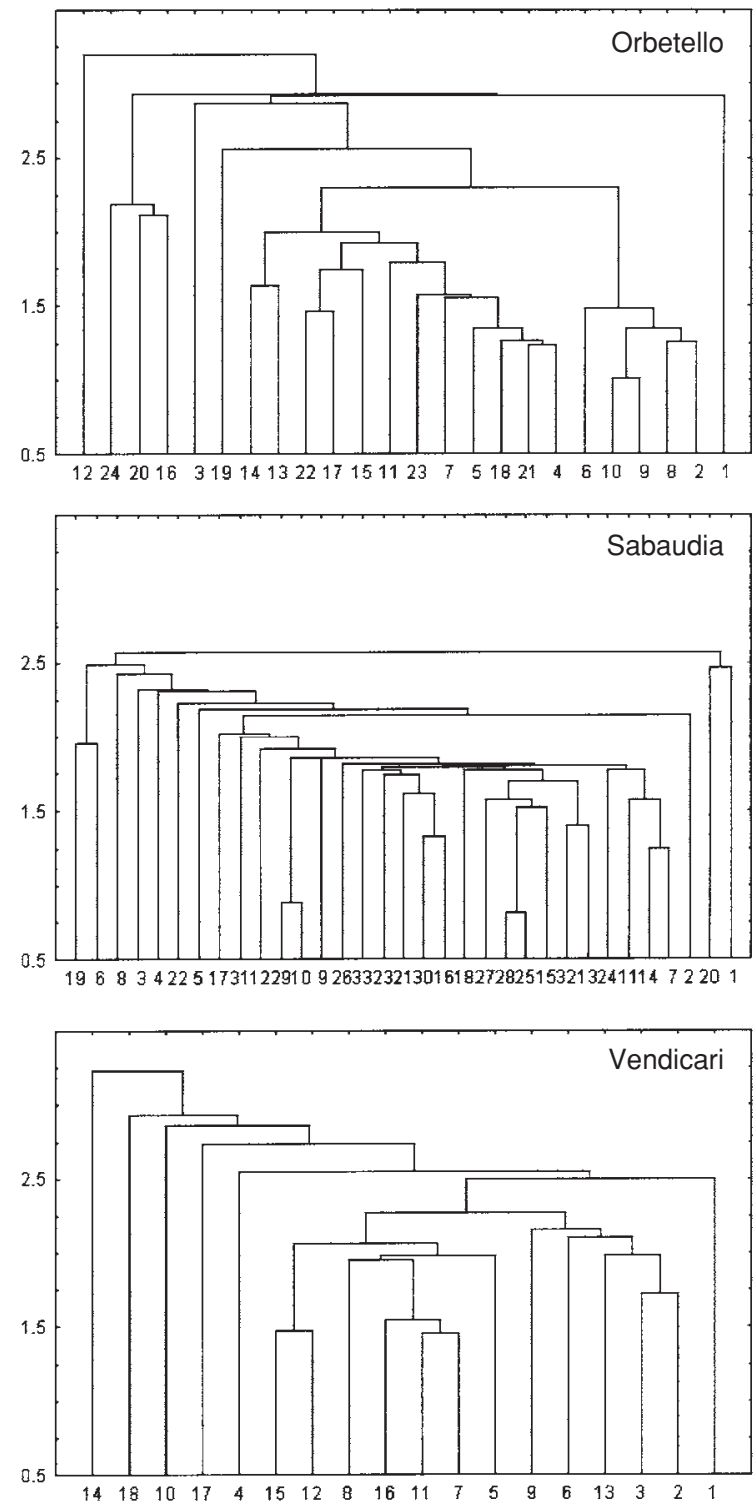

Fig. 4. Dendrograms of closest neighbourhoods, based on shortest Euclidean distances for individuals in samples of Juniperus oxycedrus subsp. macrocarpa from Orbetello, Sabaudia and Vendicari.

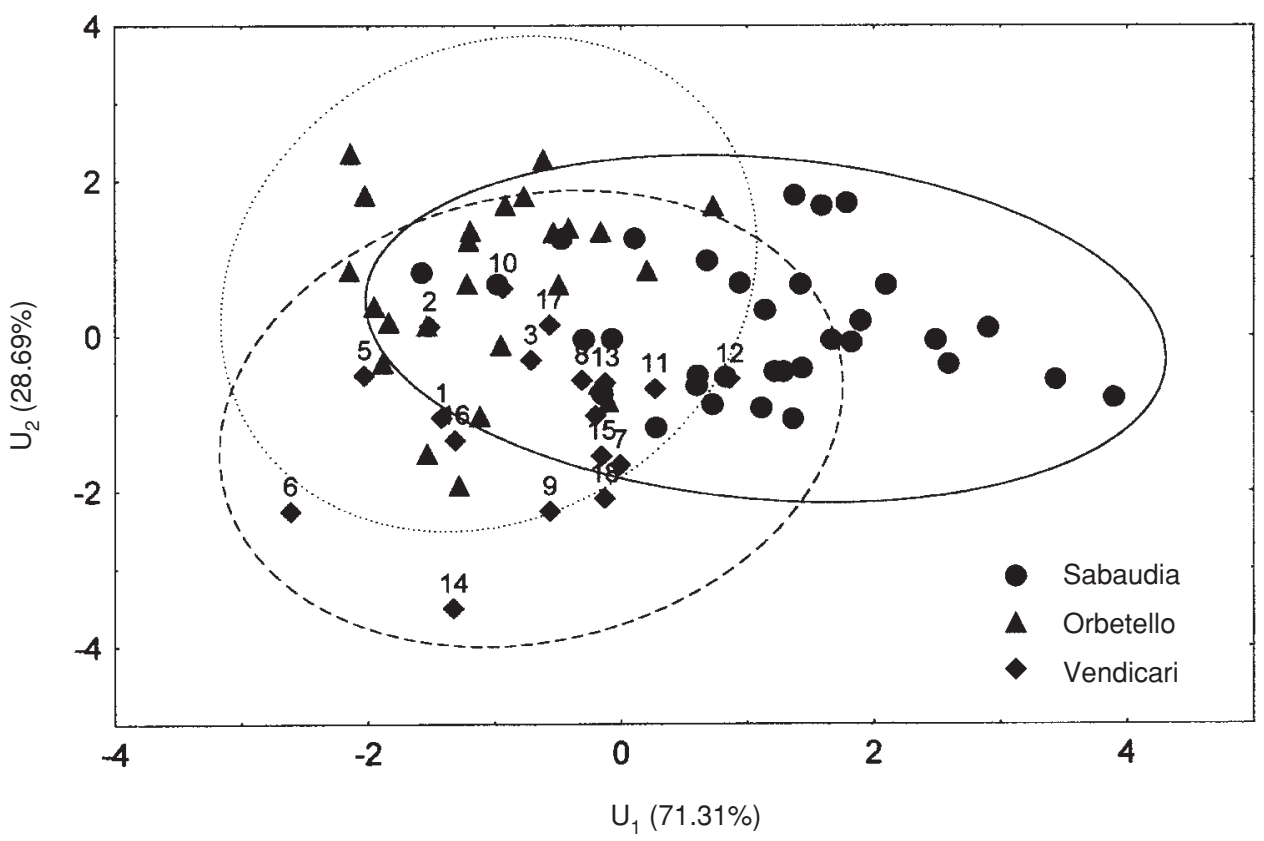

Fig. 5. Results of discriminant analysis based on characters of cones, seeds and needles for three distant populations of Juniperus oxycedrus subsp. macrocarpa on plane of the first two discriminant variables $U_{1}$ and $U_{2}$, which accounted for the total variation; confidential intervals at level $\mathrm{p}=0.05$. 

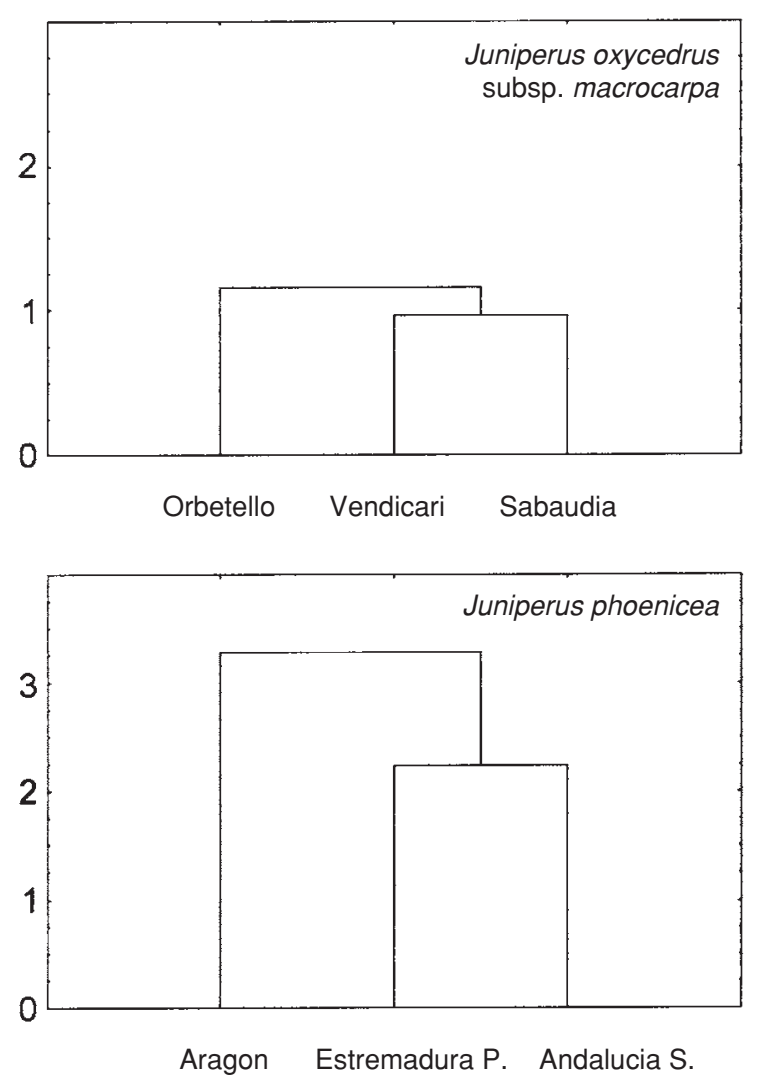

Fig. 6. Dendrograms of three samples of Juniperus oxycedrus subsp. macrocarpa from Italy and three samples of Juniperus phoenicea from Iberian Peninsula constructed on the basis of shortest Euclidean distances calculated on parallel characters (cone length, cone diameter, number of seeds per cone, seed length, seed width, cone length/wide ratio, seed length/wide ratio, cone width/number of seeds).

\section{DISCUSSION AND CONCLUSIONS}

Juniperus oxycedrus subsp. macrocarpa is an endangered taxon. The populations of the species are not numerous and in great instance isolated each other (Browicz 1996; Zaafouri and Chaieb 1999; Pastor and Juan 1999; Arista et al. 2001). It is characterized by a generally low production of cones with seeds (Ortiz et al. 1998; Arista et al. 2001; Rocio et al. 2003) and a very high proportion of aborted female cones (Rocio et al. 2003). The result of that were only three samples compared in the present study, while two other populations checked in the field in 2001 did not form cones with seeds. The low level of seed production increases the isolation of particular populations of the species, dispersed only along the coasts.

The isolation of sampled populations (Fig. 1) suggested, that they should be morphologically different. The Tukeys' test showed that 6 from the 11 examined characters differ significantly between populations (Fig. 3). The discriminant analysis, however, did not confirm this. Only needle length (character 7) discriminates statistically significantly the analysed populations, while all the other show an insignificant discriminant power.

The significant differences between populations in cone size and seed weight were found in four populations of $J$. oxycedrus subsp. macrocarpa in SW littoral Spain (Rocio et al. 2003). Cone length appears also in our study as one of the most discriminating characteristic, but statistically insignificant. The results of our study showed that most of the individuals of this taxon on the Apennine Peninsula were more or less similar. All individuals form one group on the plane between the two first discriminant variables, which, surprisingly, cover $100 \%$ of variability (Fig. 5). No one individual crosses the $95 \%$ confidence interval for the population to which it belongs. About $50 \%$ of individuals were located in the area overlapped, and only about $23 \%$ of them on the areas covered by confidence intervals of particular samples. Most different is the population from Vendicari, which has 11 individuals characteristic on the level of $\mathrm{p}=0.05$.

The marginal, most outstanding from the centers of samples are individuals characterized by a strongly elongated and/or pyriform cones, which influenced their shape and proportions (Fig. 2). Nevertheless, most of the individuals in each sample are similar. This explains also the slight variability of the species if compared with $J$. phoenicea. The average Euclidean distances between $J$. macrocarpa are about 3 times shorter than among populations of Juniperus phoenicea from the Iberian Peninsula calculated on parallel characters on the data of Mazur et al. (2003) (Fig. 6). This confirms the conclusion that the intra- and interpopulational variation of $J$. oxycedrus subsp. macrocarpa is considerably low.

Close genetic relations among individuals of $J$. oxycedrus subsp. macrocarpa have also been reported from an isolated population of this taxon on Corfu Island (Lewandowski et al. 1996). That finding was interpreted as a possible effect of colonization (Mitka 1997). In the light of the present study, and taking into account that the studied populations are not so strictly isolated as those from the Corfu Island (see Fig. 1), it should be rather regarded as a typical status of $J$. oxycedrus subsp. macrocarpa.

\section{ACKNOWLEDGEMENTS}

The study was partly supported by the Department of Botany of August Cieszkowski Agricultural University of Poznań and the Institute of Dendrology of the Polish Academy of Sciences at Kórnik.

\section{LITERATURE CITED}

ADAMS R.P. 2000. Systematics of Juniperus section Juniperus based on leaf essential oils and random amplified polymorphic DNAs (RAPDs). Biochem. Syst. Ecol. 28 (6): 515-528.

AMARAL FRANCO J. DO 1963. Taxonomic notes on Juniperus oxycedrus L. and J. macrocarpa Sm. Fedde Repert. 68: 163-167.

AMARAL FRANCO J. DO 1964. Juniperus L. In: Tutin T.G., Heywood V.H., Burges N.A., Valentine D.H., Walters S.M., Webb D.A. (eds). Flora Europaea. Cabridge, University Press. 1: 38-39.

AMARAL FRANCO J. DO 1968. Distribuição de zimbros e pomóideas na Ponínsula Ibérica. Collectanea Botanica. 7 (1): 449-481.

AMARAL FRANCO J. DO 1986. Juniperus L. In: Castroviejo S., Laínz M., López González G., Montserrat P., Muńoz Garmendia F., Paiva J., Villar L. (eds). Flora iberica. Real Jardín Botánico, CSIC, Madrid. 1: 181-188.

ARISTA M., ORTIZ P.L., TALAVERA S. 2001. Reproductive cycles of two allopatric subspecies of Juniperus oxycedrus (Cupressaceae). Flora 196 (2): 114-120.

AUCLAIR L. 1996. L'appropriation commnautaire des forets dans le Haut Atlas marocain. Cahiers Sci. Human. 32 (1): 177-194. 
BORATYŃSKI A., BROWICZ K., ZIELIŃSKI J. 1992. Chorology of Trees and Shrubs in Greece. Polish Academy of Sciences, Institute of Dendrology, Kórnik. 286 pp.

BROWICZ K. 1982. Chorology of Trees and Shrubs in SouthWest Asia and Adjacent Regions. Polish Sci. Publish., Warszawa-Poznań. 1, $172 \mathrm{pp}$.

BROWICZ K. 1996. Juniperus macrocarpa Sibth \& Sm. in the area of the "Flora of Turkey and East Aegean Islands". The Karaca Arboretum Magazine 3 (3): 117-121.

GREUTER W., BURDET H.M., LONG G. 1984. Med-Checklist 1. Botanischer Garten and Botanisches Museum, Berlin-Dahlem. $330+$ C. pp.

JALAS J., SUOMINEN J. 1973. Atlas Florae Europaeae. The Committee for Mapping the Flora of Europe and Societatis Biologica Fennica Vanamo, Helsinki. 1, 40 pp.

KAROŃSKI M., CALIŃSKI T. 1973. Grouping in multivariate populations on the basis of Euclidean distances, Algor. Biometr. Statyst. 17: 117-129.

KRZYŚKO M. 1979. Discriminant variables. Biom. J. 21: 227-241.

LEBRETON P., BAYET C., MURACCIOLE M. 1991. Le statut systématique du Genévrier oxycèdre Juniperus oxycedrus L. (Cupressacées): une contribution d'ordre biochimique et biométrique. Lazaroa 12: 21-42.

LEWANDOWSKI A., BORATYŃSKI A., MEJNARTOWICZ L. 1996. Low level of isoenzyme variation in an island population of Juniuperus oxycedrus subsp. macrocarpa (Sm. ex Sibth.) Ball. Acta Soc. Bot. Pol. 65 (3-4): 335-338.

ŁOMNICKI A. 2000. Wprowadzenie do statystyki dla przyrodników. Wyd. Nauk. PWN, Warszawa. 263 pp.

MAZUR M., BORATYŃSKA K., MARCYSIAK K., GÓMEZ D., TOMASZEWSKI D., DIDUKH J., BORATYŃSKI A., 2003. Morphological variability of Juniperus phoenicea $(\mathrm{Cu}-$ pressaceae) from three distant localities on Iberian Peninsula. Acta Soc. Bot. Pol. 72 (1): 71-78.
MITKA J. 1997. Małe, izolowane populacje na skraju zasięgu geograficznego - niektóre procesy ekologiczne i genetyczne. Wiadomości Botaniczne 41 (2): 13-34. (in Polish)

MORRISON D.F. 1990. Wielowymiarowa analiza statystyczna. PWN, Warszawa, pp. 589. (in Polish)

ORTIZ P.L. ARISTA M., TALAVERA S. 1998. Low reproductive success in two subspecies of Juniperus oxycedrus L. Int. J. Plant Sci. 159 (5): 843-847

PASTOR J., JUAN R. 1999. Juniperus oxycedrus subsp. macrocarpa. In: Blanca G., Cabezydo B., Hernández-Bermejo J.E., Herrera C.M., Molero Mesa J., Muńoz J., Valdés B. (eds). Libro rojo de la flora amenzada de Andalucía. 1. Especies en peligro de extinción. Consejería de Medio Ambiente, Sevilla, pp. 156-159.

QUEZEL P., PESSON P. 1980. Biogeographie et ecologie des coniferes sur le pourtour mediterraneen. In: Actualites d'Ecologie Forestiere. Gautjier-Villars, Paris: 205-255.

ROCIO J., PASTOR J., FERNÁNDEZ I., DIOSDADO J.C. 2003. Relationships between mature cone traits and seed viability in Juniperus oxycedrus L. subsp. macrocarpa (Sm.) Ball (Cupressaceae). Acta Biologica Cracoviensia, Ser. Botanica, 45 (2) in print.

SOKAL R.R., ROHLF T.J. 1997. Biometry: the principles and practice of statistics in biological research. Freeman W.H. \& Comp., San Francisco, pp. 359.

UNDERWOOD A.J. 1997. Experiments in ecology. Cambridge, Cambridge University Press, pp. 504.

VANDEN BERGEN C. 1990. Le Fourré à Juniperus oxycedrus subsp. macrocarpa dans les dunes du Golfe de Tunis. Belg. J. Bot. 123 (1): 5-13.

ZAAFOURI M.S., CHAIEB M. 1999. Threatened trees shrubs of the Southern Tunisia. Acta Botanica Gallica 146 (4): 361-373.

ZAR J.H. 1999. Biostatistical Analysis. Fourth edition, PreniceHall, New Jersey. 663 pp. + Appendices and Index. 